\title{
Pola Pembelajaran Daring Anak Autis Selama Pandemi Corona
}

\author{
${ }^{1}$ Novita Dwi Hartati, ${ }^{2}$ Nur Fajrie, ${ }^{3}$ Shoufika Hilyana \\ ${ }^{123}$ Prodi Pendidikan Guru Sekolah Dasar, Universitas Muria Kudus \\ Email Korespondensi: 201733101@std.umk.ac.id
}

\begin{tabular}{l}
\hline Article Info \\
Article history: \\
Article Accepted: April 112021 \\
publication: July 022021
\end{tabular}

Keywords:

Anak Autis, Pembelajaran Daring,

Pandemi Corona

Corresponding Author:

\begin{abstract}
Abstrak
Anak yang mempunyai kelainan fisik atau mental, bukan berarti harus disingkirkan tetapi hendaknya mereka tetap terpenuhi pendidikannya melalui pelayanan pendidikan secara khusus yang diharapkan dapat memperbaiki kelayakan salam taraf hidupnya. Anak penyandang autism cenderung menyibukkan diri dengan aktivitas yang hanya melibatkan dirinya sendiri dengan benda-benda mati yang disukainya. Saat dipaksa untuk bergabung dengan yang lain mereka akan mengalami kesulitan dalam berkomunikasi dengan orang lain dan bila dipaksakan akan mengakibatkan krisis emosi pada diri anak. Anak penyandang autism memiliki kecenderungan lemah dalam pengendalian emosi (sulit mengontrol emosinya). Kegiatan belajar mengajar merupakan interaksi antara anak autis yang belajar dan guru yang mengajar. Dalam upaya membelajarakan anak autis, guru sebagi model harus memiliki kepekaan, ketelatenan, kreatif, dan konsisten di dalam kegiatan pembelajaran yang dilaksanakan. Penelitian ini membahas tentang pola pembelajaran daring anak autis selama pandemi corona di SLB Cendono Kudus. Anak autis merupakan anak yang mengalami gangguan perkembangan yang sangat kompleks, meliputi gangguan perilaku, interaksi sosial, dan bahasa yang dapat diketahui sebelum anak berusia 3 tahun. Jenis penelitian ini menggunakan metode studi kasus sebagai tahapan melaksanakan penelitian. Penelitian ini akan dilaksanakan di SLB Cendono Kudus dengan subyek penelitian guru kelas autis dan kepala sekolah sebagai subyek. Penelitian ini menggunakan teknik pengumpulan data meliputi tahap observasi, wawancara, dan dokumentasi. Analisis data yang digunakan dalam penelitian ini adalah studi kasus.
\end{abstract}

This is an open access article under the Lisensi Creative Commons Atribusi-BerbagiSerupa 4.0 Internasional

\author{
Novita Dwi Hartati \\ Prodi Pendidikan Guru Sekolah Dasar, \\ Universitas Muria Kudus \\ Email:201733101@std.umk.ac.id
}

\section{PENDAHULUAN}

Anak adalah aset di dalam keluarga, kehadirannya sangat dinantikan oleh keluarga. Apalagi jika seorang anak itu sempurna, tidak ada sedikitpun kekurangan. Anak yang terlahir sempurna akan mapu untuk mengembangkan dirinya secara optimal tetapi bagi anak yang terlahir dengan kelainan tertentu memerlukan layanan khusus berupa pendidikan inklusif untuk mengembangkan dirinya (Utina, 2014). Pada kenyataannya, penyandang kelainan atau berkebutuhan khusus yang hidup di masyarakat dianggap berbeda dan bahkan menerima perlakuan buruk. Mereka juga dianggap tidak berguna dan tidak memberikan konstribusi terhadap keluarga, masyarakat, dan negara dengan keterbatasan yang dimilikinya. Perlakuan masyarakat yang kurang empati mengakibatkan sumber masalah dan beban untuk masyarakat tersebut sehingga hak mendapatkan pendidikan yang layak jauh dari harapan.

Anak berkebutuhan khusus dapat diartikan sebagai anak yang memerlukan layanan khusus untuk dapat menjalani aktivitas sehari-hari dengan baik. Hal tersebut mencakup anakanak yang mengalami permasalahan maupun yang memiliki kelebihan terkait tumbuh kembang 
yang kaitannya dengan intelegensi indera dan anggota gerak. Seperti yang diungkapkan oleh Efendi (2006) bahwa anak berkebutuhan khusu merupakan suatu kondisi yang berbeda dari ratarata anak pada umumnya. Perbedaan dapat berupa kelebihan maupun kekurangan. Dari adanya perbedaan ini, akan menimbulkan berbagai akibat bagi penyandangnya. Heward menyatakan bahwa anak berkebutuhan khusus merupakan anak dengan karakteristik khusus yang berbeda dengan anak pada umumnya tanpa selalu menunjukkan pada ketidakmampuan mental, emosi atau fisik (Rejeki \& Hermawan, 2010)

Autis adalah gangguan perkembangan pervasive pada anak yang ditandai dengan adanya gangguan dan keterlabatan dala bidang kognitif, bahasa, perilaku, komunikasi, dan interaksi (Hendita et al., 2012). Konsentrasi sangat diperlukan anak dalam belajar dan menghasilkan sesuatu yang diharapkan. Konsentrasi adalah pemusatan daya pikiran dan perbuatan pada suatu obyek yang dipelajari dan mengabaikan segala hal yang tidak ada hubungannya dengan obyek yang dipelajari (Surya, 2009). Sehingga setiap individu memusatkan dan mengarahkan perhatiannya pada pekerjaannya dan aktivitasnya dalam konsentrasi. Menurut Surya (2009), ketika perilaku negatif siswa dilakukan kepada seseorang maka hal itu akan mempengaruhi konsentrasi orang tersebut. Padahal terjadinya proses belajar mengajar membutuhkan konsentrasi belajar para pelakunya. Santrock (2009) berpendapat juga bahwa perhatian dan konsentrasi siswa adalah aspek penting dalam proses menerima dan memahami informasi.

Kenyataanya anak autis tersebut sering mengalami gangguan pemusatan perhatian, perhatian mudah teralih, sering bingung dalam mempraktikkan tugas, dan lama dalam mengerjakan tugas. Berdasarkan hasil observasi pada anak autis kemampuan emosional anak autis dalam konsentrasi pembelajaran daring masih kurang diantaranya tidak fokus mengerjakan tugas, perhatian mudah teralihkan, dan emosinya masih bisa dikendalikan. Solusi yang tepat yaitu dengan cara video call diharapkan dapat membantu meningkatkan siswa dalam konsentrasi pembelajaran daring dan dapat mengetahui karakteristik siswa autis pada saat pembelajaran daring. Maka penelitian ini bertujuan untuk mengetahui karakteristik anak autis dilihat dari emosional dan mengetahui kemapuan emosional anak autis dalam konsentrasi dalam pembelajaran daring di SLB Cendono.

\section{METODE PENELITIAN}

Pendekatan penelitian ini menggunakan pendekatan kualitatif dengan jenis penelitian studi kasus. Penelitian ini dilaksanakan di salah satu sekolah luar biasa yang berada di kota Kudus, yaitu SLB Cendono Kudus pada tahun ajaran 2020/2021. Subyek penelitiannya ini anak autis yang ada di SLB Cendono sejumlah 12 anak autis yang terdiri dari tiga orang perempuan dan Sembilan orang laki-laki. Alasan peneliti mengambil lokasi di SLB Cendono karena pada saat peneliti observasi peneliti menemukan permasalahan dalam proses pembelajaran daring yaitu kemampuan emosional anak autis dalam konsentrasi. Pembelajaran daring masih rendah sehingga aktivitas dalam konsentrasi pembelajaran daring anak autis yang diharapkan belum memuaskan. Pengumpulan data menggunakan teknik-teknik penelitian dengan observasi, wawancara dan dokumentasi. Uji keabsahan data menggunakan triangulasi sumber. Dalam menganalisis data penelitian kualitatif terdapat tiga tahapan yang harus dilakukan meliputi, mereduksi data (data reduction), penyajian data (data display), dan verifikasi atau penyimpulan (conclusion drawing).

\section{HASIL DAN PEMBAHASAN (12pt)}

\subsection{Hasil Penelitian}

Depdiknas 2006: 43 dalam (Marienzi R, 2012) mengemukakan autistik adalah suatu gangguan perkembangan yang kompleks menyangkut komunikasi, interaksi sosial. Dan anak autistik adalah anak yang mempunyai masalah atau gangguan dala bidang komunikasi, interaksi sosial, gangguan sensoris, pola bermain, perilaku, dan emosi.

Gillin (2010) menyebutkan kontak mata dan komunikasi merupakan dua syarat terjadi interaksi sosial. Selain kontak mata, bahasa tubuh atau menggunakan bahasa isyarat, dan 
ekspresi wajah juga menjadi peran penting dala berinteraksi dengan lingkungan sekitar. Mulyana (2008) mengungkapkan bahasa tubuh bertujuan untuk mempengaruhi orang lain tidak hanya dengan bahasa verbal saja tetapi juga dengan bahasa non verbal. Komunikasi tersebut menjadi instrument untuk menyampaikan perasaan-perasaan yang ada di dalam diri manusia. Seperti pada anak berinisal $\mathrm{D}$, dia mau mengerjakan tugas daring dari gurunya dengan baik.

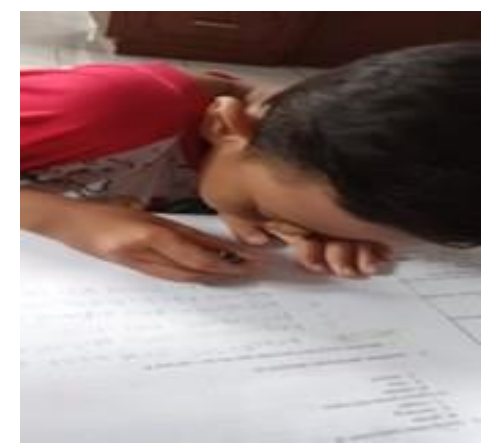

Gambar 1. Anak Mengerjakan tugas daring dari gurunya

Anak juga sudah mau menulis dan sudah bisa mandiri walaupun dibantu orangtuanya. Tetapi dia hanya kurang konsentrasi dan kadang-kadang juga suka bicara sendiri. Orang tuanya rajin ngajak dia terapi bicara dan diet makanan jadi masih bertahap. Tetapi dia sudah bisa konsentrasi walaupun terkadang bicaranya masih diulang-ulang. Sedangkan anak berinisial N, jika mengerjakan tugas masih dibantu oleh ibunya.

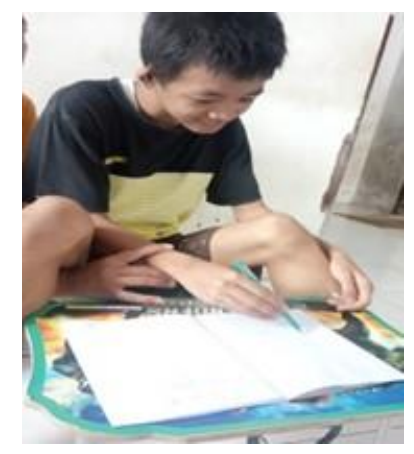

Gambar 2. Anak Belajar Menulis Dibantu Oleh Ibunya

Dia suka bicara sendiri, konsentrasinya kurang dan kadang suka nyanyi-nyanyi sendiri. Tetapi kalo diajak nyanyi bersama-sama dia tidak mau. Saat pembelajaran daring di rumah tidak ada perkembangannya, perkembangannya bagus pada saat tatap muka dia mau mengikuti dengan baik. Kalo di rumah dia suka main hp dan bicara sendiri.

Karakter adalah watak, tabiat, akhlak, atau juga kepribadian seseorang yang terbentuk dari hasil internalisasi berbagai kebijakan yang diyakini dan mendasari cara pandang, berfikir, sikap, dan cara bertindak orang tersebut. Kebajikan tersebut terdiri atas sejumlah nilai, moral, dan norma seerti jujur, berani bertindak, dapat dipercaya, hormat kepada orang lain (Kemendiknas 2010 dalam Kurniawan MI, 2015).

\subsubsection{Perencanaan Pembelajaran Daring Selama Pandemi di SLB Cendono Kudus}

Perencanaan pembelajaran yang dilakukan oleh guru dapat mempengaruhi pelaksanaan pembelajaran yang dilaksanakan, untuk itu guru dapat melakukan pengembangan dalam perencanaan pembelajaran sesuai kompetensi dasar. Jenis perencanaan pembelajaran daring selama pandemi di SLB Cendono Kudus khususnya kelas autis yaitu dengan penyusunan RPP. Majid (2007:17) mengungkapkan bahwa perencanaan merupakan proses penyusunan materi pelajaran penggunaan media pengajaran, penggunaan pendekatan dan metode pengajaran, dan penilaian dalam suatu alokasi waktu yang akan dilaksanakan pada masa tertentu untuk mencapai tujuan yang telah ditetapkan. Rosdiani (2013: 23) memberikan pemahaman bahwa pembelajaran merupakan bantuan yang 
diberikan pendidik agar dapat terjadi proses perolehan ilmu dan pengetahuan, penguasaan, kemahiran, dan tabiat, serta pembentukan sikap dan kepercayaan pada peserta didik serta membantu peserta didik agar dapat belajar lebih baik. Prosedur pembelajaran daring dilakukan dengan semua komponen pembelajaran sehingga bukan hanya menyampaikan materi saja tetapi pembelajaran memiliki makna untuk kehidupan siswa.

Penyusunan perencanaan pembelajaran daring menjadi tanggung jawab guru kelas. Sedangkan sekolah hanya sebagai penanggung jawab dan yang memberikan ketentuan kurikulum yang digunakan dalam pembelajaran. SLB Cendono menggunakan kurikulum 2013. Kurikulum 2012 memiliki kompetesi inti. Kompetensi Inti (KI) yang dimaksud dibagi menjadi 3 aspek yaitu KI 1 dan KI 2 merupakan aspek sikap, KI 3 merupakan aspek pengetahuan, dan KI 4 merupakan aspek keterampilan.

\subsubsection{Pelaksanaan Pembelajaran Daring Selama Pandemi di SLB Cendono Kudus}

Pelaksanaan pembelajaran daring selama pandemi mengacu pada perencanaan yang telah disusun pada sebelumnya. Pembelajaran daring diterapkan sekolah dalam kegiatan pembelajaran selama pandemi dengan membentuk anak bekebutuhan khusus mandiri sehingga pembelajaran bukan sekedar menulis dan mendengarkan penjelasan dari guru akan tetapi siswa juga ikut berperan aktif didalamnya meskipun berlangsung secara daring.

Proses pembelajaran daring akan berhasil apabila guru secara terus- menerus harus mengajar dengan sepenuh hati dan sabar. Sehingga ketika seorang guru mengajar dengan sepenuh hati dan sabar guru akan memberikan yang terbaik demi keberhasilan proses pembelajaran. Dalam penelitian di SLB Cendono terdapat anak autis ringan, autis sedang, dan autis ringan yang setiap kebutuhan tersebut memiliki karakteristik yang berbeda sehingga pelayanan yang diberikan oleh guru menyesuaikan karakteristik kebutuhan anak autis meskipun dilakukan dengan pembelajaran daring. Guru dapat mengetahui karakteristik anak dari perkembangan siswa saat mengikuti pembelajaran. Metode yang digunakan dalam pembelajaran daring berupa diskusi, tanya jawab secara online. Media yang digunakan berupa gambar, video call, voice note, dan aplikasi WAG (WhatsApp Group) sehingga memudahkan siswa untuk memahami materi yang disampaikan oleh guru.

\subsubsection{Evaluasi Pembelajaran Daring Selama Pandemi di SLB Cendono Kudus}

Setiap kegiatan pembelajaran berakhir guru memberikan evaluasi atas penilaian terhadap hasil belajar yang telah berlangsung. Evaluasi pembelajaran bertujuan untuk mengetahui tingkat keberhasilan guru dalam mengajar, mengetahui tingkat keberhasilan siswa dalam menerima kegiatan pembelajaran, dan untuk mengetahui sejauh mana indikator dan tujuan pembelajaran telah dicapai. Evaluasi pembelajaran daring di SLB Cendono berupa tes tertulis, ulangan harian, dan pemberian tugas harian. Guru memberikan tiga aspek penilaian dalam evaluasi pembelajaran antara lain aspek spiritual, kognitif, dan psikomotorik sesuai dengan kompetensi inti yang terdapat dala kurikulum 2013.

Aspek spiritual didapatkan dengan karakter siswa selama proses pembelajaran, aspek afektif didapatkan dengan pengamatan guru selama proses pembelajaran, aspek kognitif berupa hasil ulangan harian, tes tertulis, dan penugasan, sedangkan aspek psikomotorik berupa hasil perkembangan anak saat proses pembelajaran. Evaluasi pembelajaran daring hampir disemua kelas sama. Evaluasi meliputi tugas harian, ulangan harian, dan tes tertulis seperti PTS dan PAS. Pada evaluasi tugas harian, guru memberikan tiga butir soal berupa isian singkat disertai gambar lewat pesan WhatsApp atau lewat voice note supaya anak bisa berinteraksi langsung dengan guru.

Evaluasi merupakan bagian penting dari system pendidikan dan pengajaran dalam berbagai bentuk dan waktu pengajarannya. Evaluasi atau penilaian pada dasarnya bertujuan mennetukan evektivitas dan evisiensi kegiatan pembelajaran dengan indikator utaa pada keberhasilan atau kegiatan pembelajaran dalam mencapai tujuan pembelajaran yang ditetapkan. Evaluasi pembelajaran merupakan suatu proses yang sistematis untuk memperoleh informasi tentang keefektifan kegiatan pembelajaran dala membantu siswa mencapai tujuan yang telah ditetapkan secara optimal. Dengan demikian, evaluasi 
pembelajaran akan menetapkan baik buruknya proses dari kegiatan pembelajaran (Mukhtar, 2003 dalam Primayana et al., 2020).

\section{KESIMPULAN}

Berdasarkan hasil penelitian di SLB Cendono Kudus, maka dapat disimpulkan bahwa keberhasilan guru dalam pembelajaran daring untuk anak autis dilakukan dengan fokus pada pencapaian pembelajaran sesuai dengan proses pembelajaran berlangsung. Dalam pembelajaran daring anak autis sangat membutuhkan dorongan dan bantuan dari orang-orang di sekitarnya. Maka oleh sebab itu perhatian dan kasih sayang dari guru, orang tua, dan anak-anak lainnya sangat dibutuhkan agar tidak terus menerus tertarik dengan dunianya sendiri. Perencanaan pembelajaran daring selama pandemi di SLB Cendono Kudus terdiri dari penyusunan RPP sesuai dengan jenis ketunaannya. Pelaksanaan pembelajaran daring selama pandemi corona di SLB Cendono ada tiga kegiatan utama yaitu kegiatan pendahuluan, kegiatan inti, dan kegiatan penutup yang penyampaiannya disesuaikan dengan jenis ketunaannya. Evaluasi pembelajaran daring selama pandemi di SLB Cendono Kudus terdiri dari penilaian kognitif, efektif,dan psikomotorik. Evaluasi meliputi tugas harian, ulangan harian,, dan tes tertulis seperti PTS dan PAS. Pada evaluasi tugas harian, guru memberikan tiga butir soal berupa isian singkat disertai gambar lewat pesan WhatsApp atau lewat voice note supaya anak bisa berinteraksi langsung dengan guru.

\section{SARAN}

Saran untuk peneliti selanjutnya diharapkan dapat memperdalam pembahasan serta menambah pembahasan dari berbagai sudut pandang sehingga penelitian ini dapat menjadi acuan untuk kebaharuan.

\section{DAFTAR PUSTAKA}

Hendita, G., Kusuma, A., Si, S., Cs, M., \& Oktana, L. (2012). Sistem Identifikasi Penyakit Autis Anak Berbasis Web. 1(1), 29-41.

Nur Fajrie. Pengenalan Kegiatan Seni Rupa untuk Anak Tunanetra dalam Upaya Mengembangkan Kemampuan Sensitivitas. J Imajin. 2016;10(2):154-158.

Fajrie N, Masfuah S. Model Media Pembelajaran Sains untuk Anak Berkebutuhan Khusus. $J$ Bagimu Negeri. 2018;2(1):9-19. doi:10.26638/jbn.537.8651

Khairun Nisa, Mambela S, Badiah LI. Karakteristik Dan Kebutuhan Anak Berkebutuhan Khusus. $J$ Abadimas Adi Buana. 2018;2(1):33-40. doi:10.36456/abadimas.v2.i1.a1632

Primayana, K. H., Tinggi, S., Hindu, A., Mpu, N., \& Singaraja, K. (2020). Peran Desain Evaluasi Pembelajaran. Widyacarya, 4(2).

Hidayati, R. (2015). Peran Konselor Sekolah Dalam Meningkatkan Konsentrasi Pada Siswa Hiperaktif (Adhd). Refleksi Edukatika, 5(1). https://doi.org/10.24176/re.v5i1.431

Nazar. Perencanaan Pembelajaran Kurikulum 2013. Al - Azkiya Jurnal Ilmiah Pendidik MI/SD. 2019;4(2):112-122. doi:10.32505/azkiya.v4i2.1191

Marienzi R. Meningkatkan kemampuan mengenal konsep angka melalui metode multisensori bagi anak autis. E-Jupekhu (Jurnal Ilm Pendidik Khusus). 2012;1(3):320-331.

Kurniawan MI. Tri Pusat Pendidikan Sebagai Sarana Pendidikan Karakter Anak Sekolah Dasar. Pedagog J Pendidik. 2015;4(1):41. doi:10.21070/pedagogia.v4i1.71

Noya JE, Ambarwati KD. Gambaran Interaksi sosial anak autis di Sekolah Inklusi Multi Talenta Samarinda. J Psikol Perseptual. 2020;3(2):65-78. doi:10.24176/perseptual.v3i2.2642 